\title{
Cardioplegia using low volumic cardioplegic agents: morphological study in isolated rabbit
} hearts

\author{
Cardioplegia utilizando baixo volume de agentes cardioplégicos: estudo morfológico em coração isolado \\ de coelhos
}

Ana Paula Marques LIMA-OLIVEIRA ${ }^{1}$, Maria Tercília Vilela AZEREDO-OLIVEIRA ${ }^{1}$, Sebastião Roberto TABOGA $^{1}$, Moacir Fernandes de GODOY², Domingo Marcolino BRAILE ${ }^{2}$

RBCCV 44205-642

\begin{abstract}
s
Introduction: Pharmacological cardioplegic solution aims to eliminate the consequences of ischemic damage, which results from the misbalance between the offer and consumption of energy during the arrest of the heart beats during cardiac surgery with cardiopulmonary bypass.

Objectives: This research experimentally evaluates the structural and ultrastructural changes in isolated rabbit hearts submitted to arrest protected by a Low Volumetric Cardioplegic Solution (LVCS).

Material and Method: The study counted with a control group and two experimental groups. In group I the cardiac arrest was obtained by infusion of the LVCS for 2 hours.

In group II the experiment was conducted in the same way until the arrest protected by LVCS for 2 hours, and immediately after reperfusion was performed with the Ringer Locke $(R L)$ oxygenated solution for 1 hour. In the control
\end{abstract}

group the hearts were perfused with the $R L$ oxygenated solution for 2 hours. After the experiments, 8 samples of the left ventricle were fixed in $10 \%$ formaldehyde and $\mathbf{2 . 5 \%}$ glutaraldehyde for histological and ultrastructural analysis.

Results: The myocardial cells, the fibroblasts and the endothelial cells which were observed in the experimental groups I and II, presented with marginalization of the heterochromatin, compaction of the nucleolus, change in the morphology of the mitochondria and compaction of the cristae. Also there was an increase of the density of the mitochondrial matrix. This indicates that the nuclear structure as well as the structure of the cytoplasmic organelles were altered when compared to the cells of the control group.

Conclusion: The structural modifications were due a physiological adaptation of the cell, and not an indication of oncosis or apoptosis, suggesting that the cardioplegic solution used was efficient for the preservation of the cells.
*Instituto de Biociências, Letras e Ciências Exatas of São José do Rio Preto. IBILCE/UNESP - São José do Rio Preto-SP, Brazil **Medical School of São José do Rio Preto (FAMERP) - SP, Brazil

Department of Biology - Instituto de Biociências, Letras e Ciências Exatas - University of São Paulo (IBILCE-UNESP)

Correspondence address: Rua Cristóvão Colombo 2265

CEP 15054-000 - São José do Rio Preto - São Paulo, Brazil

Fax: 55-17-2212390 - e-mail: paula@braile.com.br
Article received on February, 2003 Article accepted on September, 2003 


\section{Resumo}

Introdução: A solução cardioplégica farmacológica busca eliminar as conseqüências do dano isquêmico, que é o resultado do desbalanço entre a oferta e o consumo de energia durante a parada dos batimentos cardíacos, nas cirurgias cardíacas com circulação extracorpórea.

Objetivo: Este trabalho avalia experimentalmente as alterações estruturais e ultra-estruturais em coração isolado de coelhos submetidos à parada protegida pela Solução para Cardioplegia de Baixo Volume (SCBV).

Método: $O$ estudo compreendeu um grupo controle e dois grupos experimentais. No grupo I, a parada cardíaca foi obtida pela infusão da SCBV por 2 horas. No grupo II, o experimento foi conduzido da mesma forma até a parada protegida pela SCBV por duas horas, imediatamente procedeu-se à reperfusão com solução oxigenada de Ringer Locke $(R L)$ por uma hora. No grupo controle os corações foram perfundidos com solução oxigenada de $R L$ por duas horas. Após os experimentos, oito amostras de parede lateral do ventrículo

\section{INTRODUCTION}

Pharmacological cardioplegic solutions try to eliminate the consequences of ischemic damage, which results from an imbalance between offer and consumption of energy during cardiac arrest in heart surgery with cardiopulmonary bypass (CPB).

In 1955, MELROSE et al. [1] launched the basis for the induction of cardiac arrest using chemical cardioplegia, infusing a sanguineous solution of potassium citrate at high concentrations to the aortic root. These researchers employed blood as the vehicle of the potassium citrate, inaugurating, with this, the era of myocardial protection with sanguineous cardioplegia. Despite of the initial diffusion of this technique, from 1959, works immerged demonstrating that potassium citrate caused cellular necrosis, which was due to the high concentrations utilized.

The method of chemical cardioplegia was abandoned until it was 'rediscovered' in 1973 [2]. The authors showed favorable results with the utilization of a crystalloid solution enriched with potassium and, thus, obtained metabolic and functional benefits for the myocardium, without the occurrence of structural alterations.

BRAILE et al. (1991) [3] divulged the technique of pharmacological cardioplegia in Latin America. They defined as its principal requisites: to try to eliminate the consequences of ischemia and create an environment in which the consumption of energy can be reduced, at the same time in which an increase in its production can be achieved to supply the basic demand. According to these authors, the cardioplegic solution should; 1) protect the heart instead of esquerdo foram fixadas em formaldeído $10 \%$ e glutaraldeído 2,5\% para análises histológica e ultra-estrutural.

Resultados: As células do miocárdio, fibroblastos e células endoteliais, observadas nos grupos experimentais I e II, apresentaram marginalização da heterocromatina, compactação do nucléolo, alteração na forma das mitocôndrias, compactação das cristas e aumento da densidade da matriz mitocondrial, indicando que tanto a estrutura nuclear quanto a das organelas citoplasmáticas foram alteradas em relação às células do grupo controle.

Conclusão: As modificações estruturais foram decorrentes de uma adaptação fisiológica da célula, não sendo indicativas de oncose ou apoptose, sugerindo, portanto, que a solução cardioplégica utilizada foi eficiente para a preservação das células.

Descritores: Soluções cardioplégicas. Miocárdio. Procedimentos cirúrgicos cardíacos injuring it with its own components; 2) have homogeneous distribution throughout the myocardium in sufficient quantities to produce the desired effects; 3 ) have its effect maintained for the duration of all the aortic clamping; and 4) be tested experimentally. Additionally, the composition of the cardioplegic solution should have elements that allow the heart to be arrested instantaneously, to supply the necessary compounds to the metabolism, to have a buffering effect against acidosis and to avoid myocardial edema.

Faced with the interest that this issue awakens and the scarcity of knowledge relating to the effects of cardioplegic solutions on cells and organelles, this study aimed at evaluating the morphological alterations of isolated rabbit heart cells. The hearts were submitted to the Langendorff System, with arrest protected using a low-volume cardioplegic

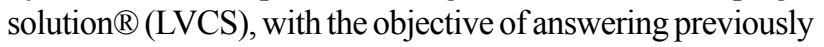
established principles.

\section{METHOD}

Nine male New Zealand White rabbit hearts were submitted to the Langendorff System [4], in the department of Research and Publications of Braile Biomedica Indústria, Comércio e Representações S/A in São José do Rio Preto, Brazil. The weights of the rabbits ranged from 2.5 to $3.0 \mathrm{~kg}$.

The rabbits received care according to the recommendations of the Committee on Care and Use of Laboratory Animals of the Institute of Laboratory Animal Resources - National Research Council - "Guide for the Care and Use of Laboratory Animals" (NIH, No. 80-23, revised in 1978, reprint in 1980) [5]. 


\section{Experimental Protocol}

The study was made up of three groups: a control group and two experimental groups.

The control group consisted of three hearts submitted to perfusion only using Ringer Locke solution for 2 hours.

Experimental group I: consisted of three hearts submitted to perfusion with low-volume cardioplegia solution (LVCS) [6] for 2 hours.

Experimental group II: consisted of three hearts submitted to perfusion with low-volume cardioplegia solution (LVCS) [6] for two hours, followed by reperfusion with Ringer Locke solution for an additional hour.

The hearts and lungs were resected from the rabbits by median thoracotomy with longitudinal sectioning of the sternum and, immediately, transferred to the modified Langendorff System. Approximately $0.5 \mathrm{~cm}$ of the aorta was preserved through which the heart was cannulated. Aortic perfusion was initiated using Ringer Locke solution (Table 1), buffered with bicarbonate at a $\mathrm{pH}$ of 7.0 , containing $1 \mathrm{~g}$ of glucose per liter, maintaining gas levels with $100 \%$ of oxygen at $37^{\circ} \mathrm{C}$, with a perfusion of $65 \mathrm{~cm} \mathrm{H}_{2} \mathrm{O}$ (approximately 47 $\mathrm{mmHg}$ ). The oxygenated solution, continually maintained the minimum tension of $\mathrm{O}_{2}$ at about $600 \mathrm{mmHg}$. Subsequently, the lungs were removed. The heart frequency was monitored by electrocardiography, with three electrodes introduced in to the left ventricle.

Table 1. Solution of Ringer Locke for infusion.

\begin{tabular}{lc}
\hline salts & CONCENTRATIONS (g) \\
\hline Solution 1 & \\
potassium chloride & 0,42 \\
calcium chloride* & 0,32 \\
Solution 2 & \\
sodium carbonate & 0,15 \\
sodium phosphate & 0,01 \\
Glucose & 1,0 \\
\hline
\end{tabular}

* Anidous and hydrate

Dilution: $50 \mathrm{ml}$ of solution 1 (chlorides) and $50 \mathrm{ml}$ da solution 2 (carbonates) - completed to $1000 \mathrm{ml}$

In the control group the hearts were kept perfused with the Ringer Locke solution for 2 hours and 20 minutes, where the first twenty minutes represented a period of stabilization. After this period, the hearts were removed from the system. About eight fragments measuring approximately $4 \times 4 \mathrm{~mm}$ were removed from the lateral wall of the left ventricle and immediately fixed in $10 \%$ formaldehyde for the histologic study, fragments from the same wall were fixed in $2.5 \%$ glutaraldehyde at $\mathrm{pH} 7.4$ for ultra-structural analysis

In the experimental groups the procedure was conducted in the same manner as far as the 20 minutes of perfusion with Ringer Locke solution for stabilization. Immediately after this period, cardiac arrest was caused with LVCS diluted in non-oxygenated Ringer Locke solution. This solution, characterized as containing the minimum volume of cardioplegic agents, is composed of a more concentrated stock solutions, to obtain cardiac arrest (Table 2), and a less concentrated maintenance solution (Table 3).

Table 2. Stock solution for induction of low-volume cardioplegia.

\begin{tabular}{lc}
\hline salts & CONCENTRATIONS \\
\hline potassium chloride & $75 \mathrm{mEq}$ \\
magnesium chloride & $40 \mathrm{mEq}$ \\
monosodium glutamate & $30 \mathrm{mM}$ \\
monosodium aspartate & $30 \mathrm{mM}$ \\
q. s. Excipient & $50 \mathrm{~mL}$ \\
\hline
\end{tabular}

Table 3. Stock solution for maintenance-reperfusion of lowvolume cardioplegia.

\begin{tabular}{lc}
\hline salts & CONCENTRATIONS \\
\hline potassium chloride & $250 \mathrm{mEq}$ \\
magnesium chloride & $15 \mathrm{mEq}$ \\
monosodium glutamate & $15 \mathrm{mM}$ \\
monosodium aspartate & $15 \mathrm{mM}$ \\
q. s. Excipient & $50 \mathrm{~mL}$ \\
\hline
\end{tabular}

The solutions, diluted in non-oxygenated Ringer Locke in the proportion of 1:100, were continuously infused using a syringe coupled to the electro-electronic infusion apparatus. For substitution of the solutions, the syringe of the apparatus was exchanged.

The induction solution was utilized only to obtain cardiac arrest, which was accomplished in about 12 minutes, infusing $3 \mathrm{~mL} / \mathrm{min}$ of the diluted solution. Subsequently, maintenance-reperfusion cardioplegia was administered at a dosage of $2 \mathrm{~mL} / \mathrm{min}$ of diluted solution for 2 hours, followed by reperfusion with Ringer Locke solution with the return of the heartbeats for more than 1 hour, when the experiment was interrupted. Also about 8 fragments measuring approximately $4 \times 4 \mathrm{~mm}$ of the lateral wall of the left ventricle were removed from each experimental group and fixed for histological analysis and fragments from the same wall were fixed for the ultra-structural study. 


\section{Histological Preparation}

The fragments of the ventricular lateral wall were fixed in $10 \%$ formaldehyde, rinsed in water, dehydrated using ethanol, cleaned using xylol and then bedded in paraplast. Histological sections with 5 ìm of thickness were obtained using a semi-automatic rotating microtomy. For each fragment around 5 histological sections were analyzed. After removal of the paraffin and hydration, the sections were submitted to staining by hematoxylineosin and impregnated with silver ions [7] to mark the nucleolar proteins. Color photomicrographies were obtained with a Jeneval Zeiss photomicroscope. Color films (Kodak -100 ASA) were utilized and developed in a specialized laboratory.

Preparation for Transmission Electronic Microscopy

The fragments from the lateral wall of the left ventricle were fixed for up to 6 hours in $2.5 \%$ glutaraldehyde diluted in a $0.1-\mathrm{M}$ phosphate buffer at $\mathrm{pH}$ of 7.3. After rinsing in a buffer, the fragments were post-fixed for 1 hour in a 1-\% solution of osmium tetroxide in the same buffer. All the fixation procedure was performed at $4^{\circ} \mathrm{C}$. The samples were dehydrated in acetone and bedded in Araldite ${ }^{\circledR}$ resin. The ultra-fine sections, of approximately $50-70 \mathrm{~nm}$, were obtained using an automatic ultra-microtomy and collected on 200 copper mesh and, subsequently, stained with uranyl acetate and $2 \%$ lead citrate. Photomicrographies were obtained using a Zeiss EM-906 transmission electronic microscope operated at $80 \mathrm{KV}$.

The histological and ultra-structural photomicrographies were performed after analysis of the samples registering repetitive patterns.

\section{RESULTS}

\section{Histologic evaluation}

Figures 1 to 3 present the histological results of the samples from experimental groups I (1A-D) and II (2A-D) and the control group (3A-D).

In the control group the histological staining technique using hematoxylin-eosin evidenced myocardial fibers with acidophil sarcoplasm and basophil nuclei with light areas, indicative of decompensation chromatin. Impregnation by silver ions demonstrated striations characteristic of muscle cells and the various nucleolar corpusculas were strongly marked (Figure 3C and 4D).

In the experimental groups the cellular structures were less well preserved when compared with the control group, however, the Figures 1A and 2A show integral nuclei and the staining by silver only demonstrated nucleolar corpusculas (Figures 1C and 2C). Note in Figures 1A-B and
2A-B cells with retracted areas showing nuclei and striated fibers with a fragmented aspect.

\section{Ultra-structural evaluation}

The experimental groups I (arrest protected with cardioplegic solution) and II (arrest protected with cardioplegic solution followed by reperfusion with a Ringer Locke solution) presented with distinct ultra-structural alterations.

In experimental group I (Figure 4A-D) the cells demonstrated marked alterations. The nuclei of the cardiac muscle cells presented with an irregular shape, with dense and electrodense heterochromatin, associated with nuclear covering and dense chromatin distributed in the nucleoplasm (Figure 4A). There is a great concentration of mitochondria which appear highly elongated and organized in parallel to each other. Note also rounded mitochondria with a vacuole inside (Figure 4B).

The muscle fibers show varying degrees of preservation, which ranges from the whole fiber with evident striations (Figure 4B) to dense fibers without characteristic striations (Figure 4A).

In experimental group II the muscle cells present nuclear characteristics similar to the control group, although irregular-shaped nuclei are evident and compacted nucleoli are common (Figures 5B and 5C).

In the mitochondria the crests are more compacted in relation to the control group and the matrix more electrodense (Figure 5D). Granules of lipids surrounded by the mitochondria are found near to the nuclei (Figures 5A and 5B). In the nuclei of fibroblasts of the experimental groups I and II, marginalization of the heterochromatin and the presence of disperse heterochromatin masses occur inside the nuclei (chromocenters). The rough endoplasmic reticule is scant and bands of collagen fibers are found around the nucleus (Figures 4C and D, 5C). Thus, similar to the muscle cells, the fibroblasts present with nuclei with re-entrances.

The control group evidenced nuclei with characteristic patterns such as heterochromatin associated with a nuclear covering, dense chromatin inside the nucleus (chromocenter) and a very-evident nucleolus (Figures 6A and B), apart from the various lipid vesicles associated with mitochondria (Figure 6A). Note also, the great amount of spherical and elongated mitochondria, rich in decondensed mitochondrial crests (Figure 6B).

Fibroblasts of conjunctive tissues adjacent to the myocardium present with nuclei with characteristic patterns. Note the abundance of rough endoplasmic reticulum around the fibroblastic nuclei (Figure 6C). The endothelium cells also demonstrate characteristic patterns such as pinocytosis vesicles and evident Golgi Complexes (Figures 6D to F). 

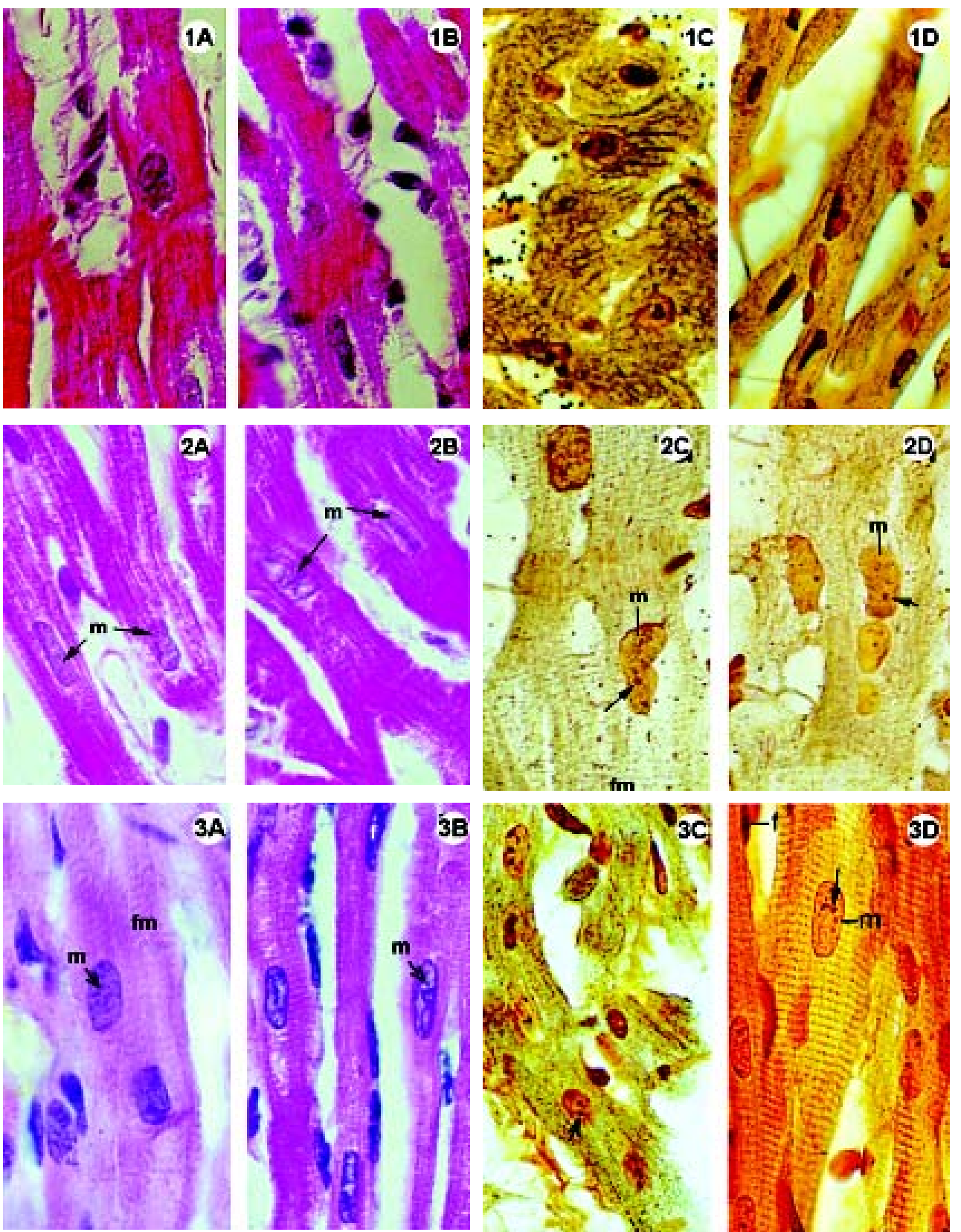

Fig. 1-3 - Histological sections of the lateral wall of the left ventricle of rabbit hearts, submitted to the Langendorff system, stained using hematoxylin-eosin (1A-B; $2 A-B ; 3 A-B)$; impregnated with silver ions (1C-D; $2 C-D ; 3 C-D)$. Magnification: $1080 x$

1A-D: Experimental Group I, heart submitted to cardiac arrest protected with a low-volume cardioplegic solution (LVCS). Staining by hematoxylineosin demonstrates basophils and myocardial fibers with acidophil sarcoplasm retracted around the nucleus and with a fragmented aspect (1AB). Impregnation by silver ions evidenced the nucleolar corpusculas positively marked (1C-D). Magnification: $1080 x$

2A-D: Experimental group II, hearts submitted to cardiac arrest protected with LVCS, followed by perfusion with oxygenated Ringer Locke solution. Staining by hematoxylin-eosin shows preserved elongated nuclei and nuclei and myocardial fibers with a fragmented appearance ( $2 A-$ B). Staining with silver ions evidenced nucleolar corpusculas and fibers with transversal striations positively marked. Magnification: $1080 x$ 3A-D: Control group, hearts perfused with an oxygenated Ringer Locke solution. A-B: Staining by hematoxylin-eosin, shows myocardial fibers with acidophil sarcoplasm and standard striation, elongated and central basophil nuclei. C-D: Impregnation by silver ions evidenced transversal striations of fibers inside the various nuclei of the nucleolar corpusculas positively marked (D). Magnification: $1080 x$

$m=$ nucleus of muscle cell; $f=$ fibroblast nucleus; $f m=$ muscle fiber; small arrow = nucleolar corpuscula. Magnification: $1080 x$ 

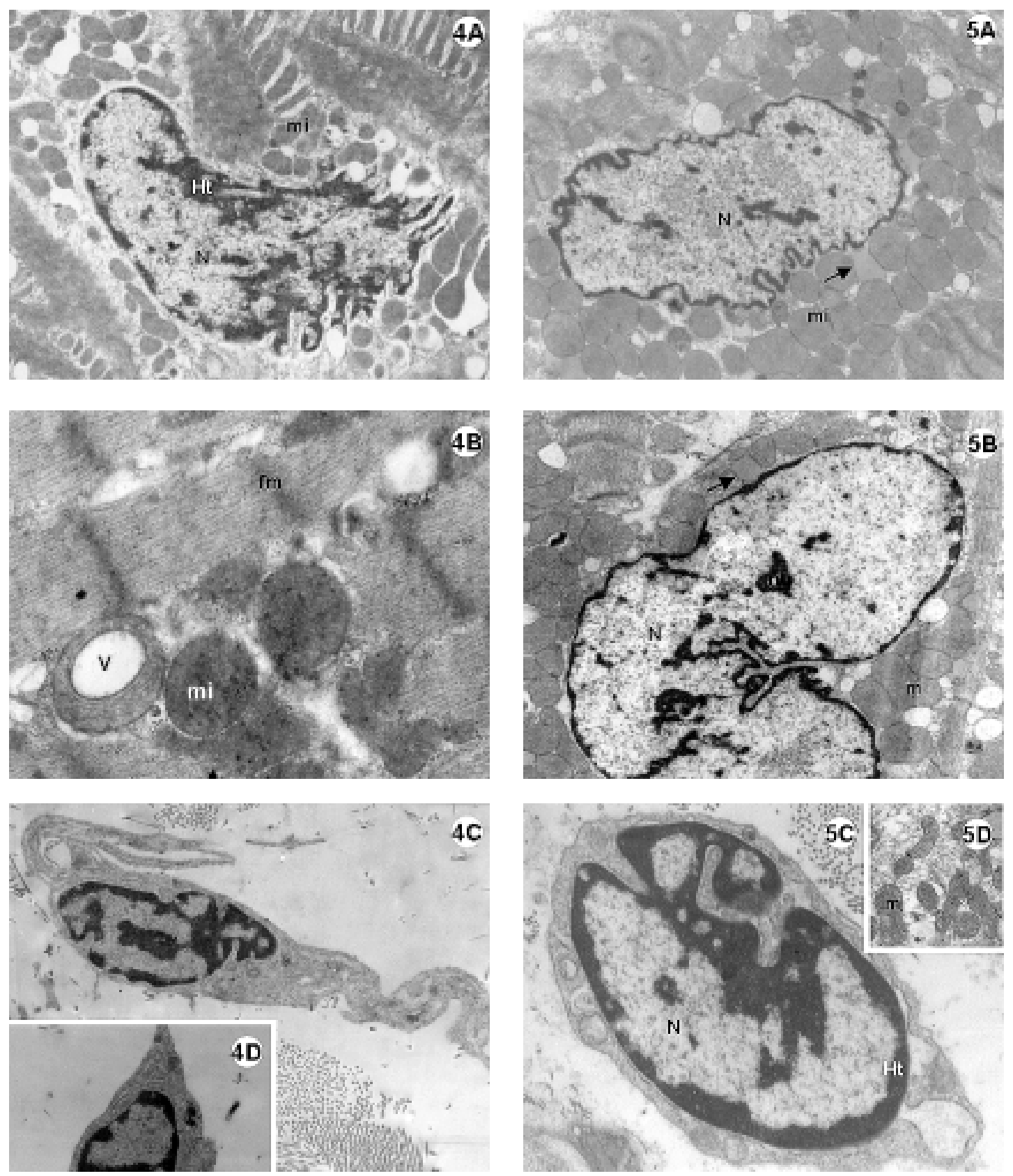

Fig. 4-5 - Electronic photomicrography of the lateral wall of the left ventricle of the rabbit heart submitted to the Langendorff System.

4A-D: Experimental group I; hearts submitted to cardiac arrest protected with low-volume cardioplegic solution (LVCS). The nucleus of the cardiac muscle cell with marginalization and thickness of the heterochromatin (ht) dispersed in masses within the nucleus (N). Mitochondria (mi) seen with an elongated shape and disorganized crests. Evidence of the loss of striation pattern of the muscle fiber with hyper-contraction. B. Details of the presence of vacuole $(V)$ within the mitochondria and between the striated fibers $(\mathrm{fm})$. C. Fibroblast and band of collagen. $D$. Details showing the lack of rough endoplasmic reticulum.

Magnification: $4 A=11600 x ; 4 B=25000 x ; 4 C=9000 x ; 4 D=7700 x$

5A-D: Experimental group II; hearts submitted to cardiac arrest protected with LVCS followed by perfusion with Ringer Locke solution. A and $B: \operatorname{Nuclei}(N)$ of the cardiac muscle cells with marginalization of the heterochromatin (ht); Chromatin apparently diffuse (cr): Nucleoli evident and compacted (nu); mitochondria with condensed crests (mi); granules of lipids around the nucleus (arrows). C. Fibroblast with a lack of rough endoplasmic reticulum. $N=$ nucleus. $D$. Details of the electrodense mitochondria.

Magnification: $5 A$ and $5 B=11600 x ; 5 C=19300 x ; 5 D=9000 x$ 

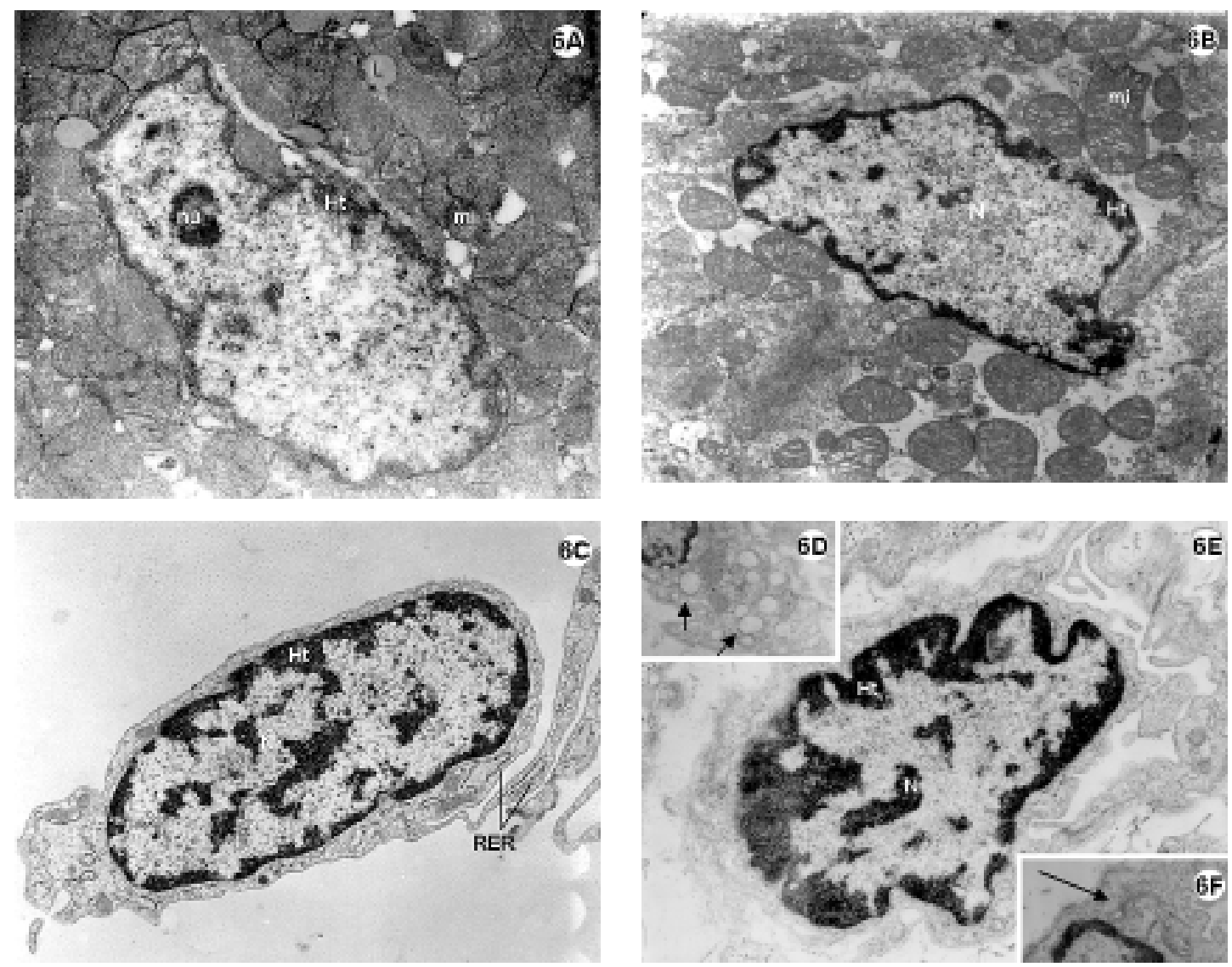

Fig. 6 - Electron photomicrography of the lateral wall of the left ventricle of the rabbit heart submitted to the Langendorff System and perfused with Ringer Locke solution for 2 hours.

6A-F: Control group. 6A-6B: Nuclei of myocardial cells $(N)$ with heterochromatin (ht) associated with nuclear covering and in disperse masses within the nucleus (chromocenters). Nucleoli (nu) evident (6A). Mitochondria (mi) rich in decompacted with granules of associated lipid (L).

6C-F: Endothelial cells. Details of the Golgi Complex (6F) (bigger arrow) well developed and of the pinocytosis vesicles (6D) (smaller arrow) characteristic of this type of cell. $R E R=$ rough endoplasmic reticulum.

Magnification: $6 A=19300 x ; 6 B, 6 C, 6 D$ and $6 F=15000 x ; 6 E=23200 x$

\section{DISCUSSION}

The structural and the ultra-structural results revealed that the hearts submitted to arrest protected by LVCS Group I, underwent more accentuated cellular alterations than those submitted to arrest protected by cardioplegic solution followed by reperfusion using Ringer Locke solution for 1 hour - Group II. The presence of vacuole inside the mitochondria of Group I is indicative of irreversible injury, however oncocytic or apoptotic cells were not found. We can infer that, although without receiving oxygen to maintain the aerobic metabolism, the structures remained in a quiescent state.

The nucleolus, organelle responsible for biogenesis of the ribosomes, was more compact in the myocardial cells of the two experimental groups. This indicates that during the time in which the heart is arrested and protected with the cardioplegic solution with future reperfusion with Ringer Locke solution, probably inhibition of the transcription of he RNA ribosomal molecules (RNAr 45S) precursors of the two ribosomal subunits, occurs. This morphologic functional aspect of the nucleolus is related to lower activity of protein synthesis in these cells, which can be indirectly confirmed by the absence of rough endoplasmic reticulum in the fibroblast. A lower protein activity in these cells reflects in the reduction of synthesis of collagen molecules, which is an important component in the extracellular matrix of the conjunctive tissue cells adjacent to the myocardial cells responsible for the sustentation and elasticity of the heart muscle [8]. 
The granules of fat found near to the nuclei are triglycerides, common in cells that depend on the degradation of fatty acids for their energy supply. The oxidative metabolism in the mitochondria is fed, not only by pyruvate produced from glucolysis of sugars to cytosol, but also from fatty acids [9]. Pyruvate and the fatty acids are selectively transported from cytosol to the mitochondrial matrix, where they are broken down in acetyl groupings producing acetyl-coenzyme $\mathrm{A}$. This is degraded in the citric acid cycle, giving origin to high-energy electrons that enter into the respiratory chain [10] and thus always depends on the presence of oxygen. Positively, this accumulation of granules is caused by the lack of oxygen, which maintains the energy cycle working, consuming oxygen.

The mitochondria are the organelle that is more susceptible to alterations in situations of anoxia or hypoxia. The presence of vacuoles in the mitochondria is one of the consequences of the lack of oxygen [11]. Additionally, these organelles are extremely plastic, constantly changing their shape. Filming demonstrates that rapid changes of shape are observed in the mitochondria of live cells. During the period of cardiac arrested by cardioplegia solution, a consequent block of the mitochondrial activities occurs. Thus, the mitochondrial crests and matrix, which constitute the most functional parts of the mitochondria, suffer alterations in their morphology [10].

The morphology of the myocardial cells, the fibroblasts and the endothelial cells, observed in the two experimental groups, indicates that both the nuclear structure and the cytoplasmic organelles were altered when compared with the cells of the control group. However, the structural modifications such as: marginalization of the heterochromatin, compaction of the nucleolus, alterations in shape, compaction of the crests and an increase in the density of the mitochondrial matrix - are caused by a physiological adaptation of the cell. Thus this is not indicative of oncosis, nor of programmed cellular death (apoptosis), suggesting, that the cardioplegic solution utilized was efficient in the preservation of the cells.

\section{BIBLIOGRAPHIC REFERENCES}

1. Melrose DJB, Dreyer H, Bentall H, Baker JBE. Elective cardiac arrest: a preliminary comunication. Lancet 1955; 2:21-2.

2. Gay Jr WA, Ebert PA. Functional, metabolic and morphologic effects of potassium-induced cardioplegia. Surgery 1973; 74:284-90.

3. Braile DM, Ardito RV, Zaiantchick M, Santos JLV, Soares MJF. Cardioplegia sangüínea normotérmica na revascularização cirúrgica do miocárdio. Rev Soc Cardiol Est de São Paulo 1991; 1:26-37.

4. Doring HJ, Dehnert $\mathrm{H}$. The isolated perfused warm-blooded heart according to Langerdorff. West Germany, Biomesstechnik-Verlag March G mbH, D-7806, 1988.

5. Committee on care and use of laboratory animals. Guide for the care and use of laboratory animals. National Research Council, Publication No 96-03, 1980.

6. Braile DM. Cardioplegia isotérmica anterógrada retrógrada de baixo volume. Apostila. $2^{\mathrm{a}}$ ed. rev. ampl. São José do Rio Preto, 1997.

7. Howell WM, Black DA. Controlled silver-staining of nucleolus organizer regions with a protective colloidal developer: a 1step method. Experientia 1980; 36:1014-5.

8. Pimentel ED. Matriz extracelular. In: Carvalho MF, ReccoPimentel SM, eds. A célula 2001. Barueri: Manole; 2001.p.217.

9. Junqueira LC, Carneiro J. Histologia básica. 9a ed. Rio de Janeiro: Guanabara Koogan; 2000. p.159-78.

10. Bruce A, Bray D, Lewis J, Raff M, Roberts K, Watson JD. Molecular biology of the cell. New York: Garland Sciences; 2002.

11. Cotran RS, Kumar V, Robbins SL. Lesão celular e morte celular. In: Cotran RS, Kumar V, Robbins SL, eds. Patologia estrutural e funcional. 5.ed. Rio de Janeiro: Guanabara Koogan; 1996. p.1-30. 